\title{
VARIEDADES
}

\section{DIFFERENT CONCEPTIONS OF RELIGIOUS PRACTICE, PIETY AND GOD-MAN RELATIONS IN THE EPISTLES OF THE IKHWĀN AL-ṢAFA'}

Carmela BAFFIONI

Istituto Universitario Orientale-Nápoles

\section{RELIGION AND FAITH IN THE IKHWĀN AL-ȘAFĀ'}

Religion is mainly addressed by the Ikhwān al-Safā' from the Muslim standpoint, as is proved by their statement that religion is twofold: its trunk (așl) is the inner believing, ${ }^{1}$ its branch $(f a r)$, one's saying and acting publicly. ${ }^{2}$

The aim of the religious Law is to secure good and to escape evil in the world ${ }^{3}$ he who does not believe in the day of judgement is not hindered from committing evil.

But the Ikhwān consider religion also from the social point of view, insofar as it emphasizes brotherhood through almsgiving and, in general, through social life as a whole: brotherhood in turn is the basis of a proper life in society (isla $a l-u m \bar{u} r$ ); and life in society is the ground for a correct political-social life (salāh al-bilād), which ultimately ensures the continuation of the race. ${ }^{4}$ Of course, religion as a deterrent from evil plays an equally relevant role within social life. ${ }^{5}$ It is likely that the divine origin of religion is maintained by the Ikhwān owing to these features. ${ }^{6}$ They remark that revelation is the highest gift given to man in the world. ${ }^{7}$ The absolute superiority of the believer in comparison to the atheist is stated, even if the believer is one who «adores anything and tries to get near God, the Almighty through anybody». ${ }^{8}$ Human 'ibāda is the highest form of

${ }^{1}$ In Ep. 42, ed. M. Gālib, 4 vols., Dār al-Ṣādir, Bayrūt, 1957, vol. III, 453, 20 we read that one of the pillars of religion is true belief (al-i 'tiqā $d$ al-sahị $h$ ).

${ }^{2}$ Cf. Ep. 42, 452, 5-6.

${ }^{3}$ Cf. Ep. 5, vol. I, 186, 19-187, 4. Beyond religion, in Ep. 42, 451, 22-23 its «dependencies» (tawäbi ${ }^{\top}$ ) are quoted, that is, piety, God-fearing, shame, sense of honour, compassion, fear and so on

${ }^{4}$ Cf. Ep. 22, vol. II, 328, 2-8.

${ }^{5}$ Cf. Ep. $42,451,15-452,3$.

${ }^{6}$ Cf. Ep. 22, 324, 5-12.

${ }^{7}$ Cf. Ep. 46, vol. IV, 84, 3-4.

${ }^{8}$ Ep. $42,483,20-21$. 
adoration, and the noblest knowledge; ${ }^{9}$ and the various prayers used in religions are deemed the highest forms of the human speech. ${ }^{10}$

Of course, the Ikhwān al-Șafâ' declare Islam as the only true religion, ${ }^{11}$ and as the religion for all, both of the elect and of common people ${ }^{12}$ (of course, even within Islam different levels of religious profession are distinguishable). ${ }^{13}$ Consequently, in Ep. 22 we can read an extensive and laudatory description of Muslim beliefs and rites. ${ }^{14}$ Moreover, the Ikhwān urge the believer to consistency, both in his personal and in his public life, and to observance of the faith without fanaticism $;{ }^{15}$ they repeat the invitation to advance in one's own religion through a careful examination of conscience, and through the minimizing of other people's mistakes and $\operatorname{sins}^{16}$ as well.

The strictly Muslim standpoint of the Pure Brethren's allusions to religion is also demonstrated by their definition of faith, as «assent to that which is revealed», ${ }^{17}$ or «confessing what (the prophets) have said, and acknowledge the hidden things they have communicated $\gg .{ }^{18}$

Faith is often addressed in the Epistles, because it entails several angelic virtues and intellectual states, which are the distinguishing marks of believers versus atheists and hypocrites. ${ }^{19}$ Nevertheless, many learned men do not know who the true believer and unbeliever are, and so they charge one another with infidelity and curse one another without reason. ${ }^{20}$

In Ep. 46 (where the whole ch. 4 deals with the external and inner sides of faith), faith conditions are also listed, such as: trust in God, purity of heart in deeds and prayer, patience, contentment with fate and divine decree, fear of God

${ }^{9}$ Cf. Ep. 49, vol. IV, 211, 13-19.

${ }^{10} C f$. Ep.31, vol. III, 130, 13-16.

${ }^{11}$ Islam is the best religion ( $c f$. Ep. 22, 286, 1); the Muslim one is the last of religious Laws, and Muhammad the seal of prophecy (cf. Ep. 31, 143, 12-14).

${ }_{12}$ Cf. Ep. 22, 285, 17-18; Ep. 30, vol. III, 77, 16-17.

${ }^{13}$ Cf. Ep. 48, vol. IV, 176, 13-177, 10

${ }^{14}$ Cf. Ep. 22, 285, 6-286, 10.

${ }^{15}$ Cf. Ep. 42, 429, 2-7.

${ }^{16}$ Cf. Ep. $42,501,9-16$

${ }^{17}$ Cf. Ep. 41, vol. III, 392, 5 and, for similar statements, Ep. 9, vol. I, 344, 4-6 e 346, 17-21. In Ep. 41 (whose meaningful title is «On definitions and descriptions») we find also defined Islam, religion, infidelity, polytheism, unbelief, disobedience, obedience, the hereafter, reward, punishment, that which is good (al-ma'rūf), that which is forbidden (al-munkar), the worker price (cf. vol. III, 392, 5-19), and later: Paradise (in five ways), Hell (two definitions), resurrection (ba th and qiyāma), sleep after death, congregation, computation and the way (șirät $)$ (cf. vol. III, 397, 20-398, 10).

${ }^{18}$ Cf. Ep. 9, 335, 12-337, 8 .

${ }^{19}$ Cf. Ep. 9, 337, 23-338, 11. On the unbelievers see also Ep. 47, vol. IV, 133, 6-8 (the prophet is their sworn enemy), and Ep. 49, 243, 19-21 (after death, they are destined to damnation).

${ }^{20} \mathrm{Cf}$. Ep. 46, 61, 12-14. 
and trusting only Him, adherence to the Lawgiver; renouncing the world and craving the hereafter. ${ }^{21}$

\section{THE POLITICAL VISION OF RELIGION}

But religion is addressed in the Epistles mainly from the political point of view, once again according to a well-spread tenet in Islam, that religion (din) and kingship (mulk) are twins. While religion is the basis of kingship, ${ }^{22}$ kingship has the task of keeping religious Law alive. ${ }^{23}$ Insofar as prophecy facilitates human salvation, ${ }^{24}$ kingship should make the Law applied, and urge the community to faith. Though such issues cannot be dealt with in this paper, it is clear that a political conception of religion implies both the question of religious wars and of conversion, and, consequently, God-man relations are strongly dependent on the behaviour of temporal governments.

Temporal authorities establish religion, while religion must urge the authorities to oblige people to observe its Law, freely or compulsorily. For this reason the followers of every religion kill one another, in order to obtain the submission of all to the Law of their own religion. ${ }^{25}$ This shows that religious wars, or even attempts at violent assimilation, are placed by the Ikhwān in a mainly political context. In this context, obstinacy appears as the worst $\sin ;^{26}$ and on the other hand, of course, submission to God is considered as the highest good. ${ }^{27}$

The Ikhwān clearly attribute to Muhammad the purpose of propagating his own religion, so that it is finally widespread above all others (and especially

${ }^{21} C f$. Ep. 46, 68, 14; 70, 4; 72, 2; 73, 5-9; 75, 19; 76, 11-13; 81, 4. At 81, 11-17 we read that the believers, the wise men and the prophets renounced the world and craved for the hereafter because they had understood its true nature and realized that it is superior to the world. Actually, comparison with the world is the best way for knowing the hereafter.

${ }^{22}$ Cf. Ep. 22, 299, 18-20.

${ }^{23}$ Cf. Ep. 8, vol. I, 292, 9-18.

${ }^{24} C f$. also Ep. $42,481,13-16$

${ }^{25}$ Cf. Ep. 22, 367, 5-369, 14

${ }^{26}$ Cf. Ep. 22, 308, 14-15.

${ }^{27} C f$. Ep. 31, 153, 1-155, 3. But religious wars are addressed by the Ikhwān also from a theoretical point of view. In fact, a basic postulate is (again according to the Muslim shahāda) that God is one and unique. But, the Ikhwān note, if the majority of learned men agree on the unity of God and on the characteristics of the Creator, and acknowledge the Prophet and the holy Book, following the shari' ' $a$, they, nonetheless, disagree on the way the shari ' $a$ has been transmitted, and about its meanings. This introduces a very important topic, that of the language (or rather languages) through which prophecy is expressed. But I am obliged to postpone this issue for another occasion. 
above polytheism ${ }^{28}$ ). A kind of «panislamism» is even forecast, for the time when disputes among the various schools come to an end. ${ }^{29}$ But we should add that the Ikhwān appear substantially inclined to a «soft» approach to attempting conversions. Accordingly, to those who deem it lawful to shed their opponents' blood like Jews, kharijites and «all those who deny the Lord» the Merciful are opposed, who grieve over sinners and beg God's forgiveness for them: such are the pious, the ascetics, the pure believers, and «the school of our honoured Brothers» as well. ${ }^{30}$

In spite of this, we are told that everyone is obliged to obey his own political ruler, only while this is compatible with his own faith. And the Ikhwān know that everyone is convinced of his own belief and consequently refuses to commit himself to another religion. ${ }^{31}$ This is because, in general, people incline to follow their fathers' religion, unless its falsehood is apparent, and the truth of another is evident. ${ }^{32}$

In this frame, of course, the Ikhwān side with the $S h \bar{l}$ ' $a$, even if with no complete consistency. ${ }^{33}$ In fact, as is well known, it is the bee (the symbol of the imāms) who declares she has been given both prophecy and sovereignty. ${ }^{34}$ Moreover, the Ikhwān sharply regret that caliphs kill the imāms. ${ }^{35}$

\section{THE «FRIENDS OF GOD»}

The allusion above, to «the pious, the ascetics, the pure believers», introduces us to the last issue of this paper. From all that we have said up to now, it should be clear that the Ikhwān al-Șafā' are, in general, very far from any mystical or ascetic approach to religion. ${ }^{36}$

${ }^{28}$ For the struggles of Muhammad's followers against the Meccan polytheists see also Ep. 44, vol. IV, 23, 22-24, 7 .

${ }^{29}$ Cf. Ep. 31, 164, 18-20.

${ }^{30}$ Cf. Ep. 45 , vol. IV, 44, 8-13.

${ }^{31}$ Cf. Ep. 42, 536, 23-537, 7.

${ }^{32}$ Cf. Ep. $42,501,2-8$.

${ }^{33}$ Cf. my paper Conversion in the Epistles of the Ihwãn al-Safã', in Raccolta di studi in memoria di Luigi Cagni, Napoli, I.U.O., in print.

${ }^{34}$ Cf. Ep. 22, 301, 17-20.

${ }^{35}$ Cf. Ep. 22, 286, 11-13.

${ }^{36}$ Even if, in general, hostile to asceticism ( $c f$. e.g. Ep. 22, 359, 13-360, 6), in some passages the Ikhwān seem in favour of renouncing the world. $C f$. e.g. -with reference to refraining from food-, Ep. 9, 358, 16ss.; in Ep. 25, vol. II, 444, 13 they speak of asceticism as ordered by the Prophets; in Ep. 27, vol. III, 8, 16-17 they list mysticism, asceticism, Christian monachism and attachment to the hanafi religion as means for perfecting souls; shortly afterwards, at 15, 9 worship, mystical practice, adherence to the school of the «Divines (rabbäniyyin)» are quoted among the praiseworthy attributes. 
This notwithstanding, we meet with frequent allusions to the so-called «Friends of God» (awliyă' Alläh), a name which, etymologically, emphasizes the closeness of these people to the Creator, ${ }^{37}$ and by which mystics are often meant.

These people are variously and richly described in the Epistles, through the listing of their «distinguishing marks». I shall resume here their main properties, among which we have: ${ }^{38}$

a) Personal characteristics and qualities, such as: love, chastity, moderation, calm, charity, prudence, unselfishness, kindness, mildness, sobriety, zeal, endurance, courage; praiseworthy behaviour; they perform deeds «against nature»; they act honourably and refrain from that which is forbidden; they resemble angels in their deeds;

b) qualities in relation with other people, such as: reliability, altruism, friendship, sincerity, compassion, justice, generosity, patience, forgiveness, piety, tolerance; other people trust and honour them;

c) their behaviour towards God: trust and fear of God; they crave to see Him and find this pleasure while still alive, thanks to their zeal; have no intermediaries for getting close to God; have only God in mind; are not afraid of death because they look forward to meeting God; are ready to obey their ruler according to religious Law; they act as if God sees them and they see God; for them, all places and times are the same; ${ }^{39}$ they find their reward already on this earth; ${ }^{40}$

d) God's position towards them: God speaks of them in many Qur'anic verses, and so does the Prophet in many akhbär; they are absolved from their sins, and go to Paradise after death ${ }^{41}$ God reveals himself to them while they are still alive; Iblīs has no power on them.

As we see, we are here faced with the description of the best God-man relation one could ever imagine. But are we entitled to see in these awliyā' Allāh the «mystics» of «traditional» Islam? I think we should not. In fact, in the

${ }^{37}$ Cf. e.g. Ep. 22, 376, 22, 24 and 377, 19; Ep. 38, vol. III, 298, 16, 21, 24; 299, 4 and 9 (together with ahl [al-]mawadda: the «Fedeli d'Amore» of Dante?); in Ep. 43, vol. IV, 9 «the books of the Friends of God» are spoken of.

${ }^{38}$ Cf. Ep. 9, 333, 8-334, 16; 335, 12-337, 8; 338, 13-342, 16; 357, 6-12; 359, 14-360, 13; 362, 1-383, 18; Ep. 22, 376, 25-377, 5; Ep. 30, 65, 19-24; Ep. 37, vol. III, 282, 4-11; Ep. 38, 288, 4-5; $289,12-17 ; 290,16 ; 293,16 ; 311,5-313,21$; Ep. 39, vol. III, ch. 7 (336, 1-337, 7); ch. 11 (342, 1-343, 6); Ep. 42, 483, 5ss.; ch. 52; ch. 53, 530, 12-531, 4; Ep. 49, 243, 16-21.

${ }^{39}$ The Ikhwān say: every day is for them like one and the same Friday, every place is for them like one and the same mosque, all their movements are an act of worship towards God.

${ }^{40}$ In this, they are opposed to the Christian monks, see the story in Ep. 9, 338, 22-342, 16; Christian monks are quoted also in Ep. 44, 32, 2-6.

${ }^{41}$ Like, at any rate, any believer. 
Epistles the «Friends of God» are called «the cream of creation», «persons of understanding, view, and mind», the «gnostics endowed with mental vision».

Moreover, they have very special intellectual gifts, which also condition their renunciation to the world and longing for the hereafter. First of all, they are said to be acquainted with resurrection and other eschatological Muslim realities, contrary to many learned men, jurists and philosophers; secondly, they know the true nature of angels and their inspiration, and of devils and their temptations; thirdly, they are acquainted with the Lord, the secrets of prophecy and the philosophical propaedeutics; in that they are the Prophets' heirs, and like prophets they are able to speak about the hereafter; fourthly, they know the true natures of things and have cosmological esoteric knowledge. They are aware that each particular soul is a faculty effused from the Universal Soul; that the Universal Soul is, in her turn, effused from the Universal Intellect; that the Universal Intellect is a light effused from the Absolute Body; that God is the supreme light, that He is the pure Being, the source of every good, eternal and everlasting, and that also the particular souls are lights, effused in the world from the Universal Soul.

These are, of course, knowledge very far from the current religious one. Finally, some of the Ikhwān al-Ṣafā' are, themselves, called «the Friends of God», and the «Brethren» and the «Friends of God» are even spoken of together:42 finally, in the passage quoted above, together with the pious, the ascetics, the pure believers, are placed just the Ikhwān al-Ṣafā'.

The question whether the Ikhwānian Friends of God are the Shi 'ite imāms has to be postponed for another occasion. But I emphasize here the fact that they are considered as «having a firm grasp in science», by the same words of Cor., III, 7 which, according to the Ismaili perspective, can be referred only to the imāms ${ }^{43}$ In many places, moreover, the Ikhwān urge one to imitate the «Friends of God» $; 4$ and, finally, just as the Ikhwān regret that caliphs kill the imāms, they also regret the murder of the «Friends of God». ${ }^{45}$

At any rate, this short introduction to the Ikhwānian special conception of the awliyā' Allāh should confirm that the encyclopaedia stresses dìn and 'ibādāt from the very Muslim point of view; neither is missing a critical examination of the historical developments of the dawning Islam.

${ }^{42} C f$. Ep. 30, 78, 12-19 and 82, 14, respectively.

${ }^{43}$ Cf. Ep. 9, 323, 18-20 (rāsikhūna fi 'l-'ulūm al-ilāhiyya); 357, 6 (rāsikhūna fì 'ilmihā); 375, 16 (where al-hikma al-bāligha is hinted at); Ep. 46, 82, 19 (räsikhina), 21.

${ }^{44} C f$. Ep. 9, 334, 10-15 and 360, 8-13; Ep. 22, 179, 8.

${ }^{45}$ Cf. Ep. 22, 361, 4-22. 